\title{
Estimation of Plasma Levels of Zinc, Copper and Selenium in Yemeni Qat Chewer women
}

\author{
Ekram Al-Eryani, Munira Dughish, Molham Al-Habori \\ Department of Biochemistry, Faculty of Medicine and \\ Health Sciences University of Sana'a, Yemen
}

\begin{abstract}
As no previous study has evaluated zinc, copper, and selenium in Yemeni women chewing qat, the purpose of this study was to estimate the effects of chewing qat on their plasma levels of zinc, copper, and selenium. A total of forty seven healthy, adult, Yemeni women, were selected and grouped in to 24 healthy Yemeni regularly chewing qat, and 23 healthy women non-chewing qat. Plasma samples were collected from two groups for zinc, copper, and selenium analysis by atomic absorption. The plasma levels (mean $\pm S D$ ) of zinc, copper, and selenium in Yemeni women chewing qat were $40 \pm 610.6 \mu \mathrm{g} / \mathrm{dl}, 70 \pm 34.6 \mu \mathrm{g} / \mathrm{dl}, 50 \pm 15.2 \mu \mathrm{g} / \mathrm{dl}$ respectively and the mean \pm $S D$ of zinc, copper, and selenium in Yemeni women non-chewing qat were $60 \pm$ $14.2 \mu \mathrm{g} / \mathrm{dl}, 40 \pm 12.7 \mu \mathrm{g} / \mathrm{dl}$, and $140 \pm 40.6 \mu \mathrm{g} / \mathrm{dl}$. These results, high content of copper and low level of zinc and selenium among women chewing qat can be attributed to the antagonistic effect of qat content as (Cathinone, Copper, Vitamin C, and tannin. So deficiency of zinc and selenium among women chewing qat may increase the risk of disease.
\end{abstract}

Key words: Cath edulis, Qat, Zinc, Copper, Selenium, Yemen.

\section{INTRODUCTION}

The chewing of qat (or khat) leaves (Catha edulis Forsk) is widely practiced in East Africa and parts of the Middle East, such as, Yemen where it forms a deep- rooted social and cultural function ${ }^{(1)}$. This habit has now spread to ethnic communities in the rest of the world, including Britain such as the Somali communities in South Wale and London. The pleasure derived form qat chewing is attributed to the euphoric actions of its content of (-)-s -cathinone. A sympathomimetic amine with properties described as similar to those of amphetamine ${ }^{(2-4)}$.
Processed leaves and roots are used to treat influenza, cough, gonorrhea, asthma and other chest problems. The root is also used for stomach ache and an infusion is taken orally to treat boils, even though qat is mainly a social drug, it is taken to treat illness such as malaria ${ }^{(5,6)}$.

Some people mentioned that the main reason for chewing is an enhancement of socialization and that the ceremony is a nice way of spending time with friends, not as much as the physical effect of qat such as staying awake or getting "high". Different production areas and varieties of qat are reported to give dissimilar effects on the same chewer $^{(7)}$. 
The active ingredient in qat is alkaloid cathinone, sometimes called "natural amphetamine. The qat is preferable chewed within two days after harvesting, after that leaves loose much of the desired effect ${ }^{(8)}$.

Qat contains a lot of chemical components that may have different effect on the body system, such as alkaloids, trepenoids, flavonoids, sterols, glycosides, sterols, tannins and more than 10 amino acids including tryptophan, glutamic acid, glycine, alanine and threonine ${ }^{(9,10)}$.

Also, qat contains trace amount of vitamins, including ascorbic acid, riboflavin, niacin, and carotene ${ }^{(10)}$. Elements includes, copper, zinc and nickel in large amount if compared to cobalt, cadmium and lead beside a negligible amount of fluorine ${ }^{(11)}$.

The interest in trace elements research in clinical medicine has become an exciting frontier, during the last two decades; the number of publications on that subject has progressively increased .They are essential elements needed in minute quantities for the proper growth, development and physiology of the human body ${ }^{(12)}$.

Trace elements can either be, essential or non-essential. Essential trace elements are those that are required by an organism to maintain normal complex metabolism (e.g. metalloproteins) which are required in enzymatic activities and can play structural role in connective tissues or cell membranes, Non-essential elements are considered toxic and are not required for physiologic process. Without essential trace elements the organism can not complete its life cycle or achieve normal healthy growth ${ }^{(13,14)}$.

Copper (cu) is an oligoelement which is a constitutional part of each cell .Atomic weight of copper is 63.57, specific weight $8.93-8.95$, and atomic number 29 . About $96 \%$ of plasma copper is firmly bound to ceruloplasmin ${ }^{(13)}$.. The essential role of copper in maintaining normal health in both animals and humans has been recognized for many years. Copper is required with iron for synthesis of hemoglobin. It works with many enzymes such as those involved in protein metabolism and hormone synthesis also, important in synthesis of ATP and collagen. Deficiency of copper causes low red blood cells count and poor growth. Excess intake of copper can cause vomiting, nervous system disorder and Wilson's disease ${ }^{(15,16)}$.

Zine $(\mathrm{Zn})$ zinc is an essential element found in tissues of animals and plants even in normal ambient concentration. Zinc is the most ubiquitous of trace element involved in human metabolism. More than one hundred specific enzymes required zinc for their catalytic function. If zinc removed from the catalytic site, the enzyme activity is lost, replacement of zinc restored the activity again. Zinc is a participant in all major biochemical pathways and plays multiple roles in the perpetuation of genetic material, including transcription of DNA, translation of RNA, and ultimately all division when the supply of dietary zinc is insufficient to support these function, biochemical abnormalities and clinical signs may develop. Studies in individuals with acrodermatities 
enteropathica, a genetic disorder with zinc malabsorption resulting in severe deficiency; have provided much insight into the functional outcomes of zinc deficiency. This include impairments of dermal, gastrointestinal, neurologic and immunologic system ${ }^{(17)}$

Selenium: selenium was discovered by Berzelius in 1817 . Selenium is associated with antioxidant activities and is an important component of the enzyme glutathione peroxidase which reduces both $\mathrm{H}_{2} \mathrm{O}_{2}$ and organic peroxides formed in the cell, so the deficiency of selenium resulted in oxidative damage to red blood cells, degenerative conditions of aging including premature aging, lipofuscin deposition and chronic inflammatory conditions and an endemic cardiomyopathy (Keshan disease) which was related to reduced activity of an enzyme, glutathione peroxidase. Selenium protects against chromosomal damage, stimulates DNA repair, and modulates the rate of cell division. Selenium also, has an inhibitory effect upon chemical carcinogens and accelerates their detoxification. So, deficiency of selenium, in conjunction with low vitamin $\mathrm{E}$, has been related to a greater incidence of lung, skin and gastrointestinal cancers in humans ${ }^{(\mathbf{1 8 , 1 9})}$ Selenium also, enhances antibody formation. Therefore, selenium deficiency may impair the normal immune response ${ }^{(20)}$ Selenium also, has been shown to be related to thyroid function. The enzyme: Iodothyronine deiodinase (IDI) is a selenoenzyme, so, deficiency of selenium reduced IDI $^{(\mathbf{1 8})}$. Selenium deficiency is also, associated with diabetes mellitus ${ }^{(21)}$.

\section{SUBJECTS \& METHODS}

A total of forty seven Yemeni healthy adult women aged 25-35years were randomly selected after obtaining ethical permission and divided into two groups: Group 1 (N: 24 healthy) not diabetic (Mean fasting blood glucose $=100 \pm 21.843 \mathrm{mg} / \mathrm{dl}$.) non anemic (mean hemoglobin $=14.4$ $\pm \quad 0.904 \mathrm{~g} . / \mathrm{dl}$.), and regular qat chewers. Group 2, (N: 23 Healthy non diabetic (Mean fasting blood glucose $=95 \pm 11.20 \mathrm{mg} / \mathrm{dl}$.) and non anemic (Mean hemoglobin $=14.9 \pm 1.048$ g./dl) non qat chewers as control group; Seven milliliter $(7 \mathrm{ml})$ blood sample were collected from each subject part was placed in heparinized tube for estimation of trace elements (copper, Zinc \& selenium), another part placed in $\mathrm{K}_{2}$ EDTA containing tube for estimation of hemoglobin and the last part was placed in plain tube to obtain serum for glucose estimation. Heparinized tubes, centrifuged of $1500 \mathrm{rpm}$ for five minutes, plasma obtained was stored in a chest freezer at a temperature of $20^{\circ} \mathrm{C}$, plasma trace elements (copper, Zinc and selenium) level were determined by atomic absorption spectrophotometer Perkin Elmer 2380Model. Hemoglobin determined by colorimetric Drabkin method and fasting blood sugar was performed on automated analyzer (Roche Milan Italy). 
STATISTICAL ANALYSIS:

Data obtained was analyzed using SPSS version 16 statistical software package. Results were expressed as mean \pm SD and a $\mathrm{p}<0.05$ was considered significant.

\section{RESULTS}

As shown in table 1 and figures 1 , 2 and 3, the mean, plasma level of zinc in qat chewer was $40 \pm 10.6$ $\mu \mathrm{g} / \mathrm{dl}$ and in control group was $60 \pm$ $14.2 \mu \mathrm{g} / \mathrm{dl}$ which is significantly lower than that of control group, $\mathrm{P}<0.001$. The means of plasma levels of copper in qat chewer and in control group were $70 \pm 34.6 \mu \mathrm{g} / \mathrm{dl}$ and $40 \pm$ $12.7 \mu \mathrm{g} / \mathrm{dl}$. That of the qat chewer was significantly higher than that of control group $\mathrm{P}<0.001$. In contrast, the mean plasma level of selenium in qat chewer was $50 \pm 15.2 \mu \mathrm{g} / \mathrm{dl}$ and in control group was $140 \pm 40.6 \mu \mathrm{g} / \mathrm{dl}$ which is significantly lower than that of control group $\mathrm{P}<0.001$. The mean values of $\mathrm{Hb}$ and fasting serum sugar in the two groups were (14.4 \pm $0.904 \mathrm{~g} . / \mathrm{dl}$. and $100 \pm 21.843 \mathrm{mg} . / \mathrm{dl}$. Versus $14.9 \pm 1.048$ g./dl and 95 $\pm 11.20 \mathrm{mg}$./dl respectively. There was no significant difference between these two groups $\mathrm{p}>0.05$.

Table 1: The plasma mean levels of trace elements (zinc, copper and selenium), blood $\mathrm{Hb}$ and fasting serum glucose in controls and qat chewers

\begin{tabular}{|l|l|l|}
\hline & $\begin{array}{l}\text { Women qat chewer } \\
\text { No= 24 } \\
\text { Mean } \pm \text { SD }\end{array}$ & $\begin{array}{l}\text { Women non-qat chewer } \\
\text { No=23 } \\
\text { Mean } \pm \text { SD }\end{array}$ \\
\hline Zinc, $\mu \mathrm{g} / \mathrm{dl}$ & $40 \pm 10.6$ & $60 \pm 14.2$ \\
Copper,$\mu \mathrm{g} / \mathrm{dl}$ & $70 \pm 34.6$ & $40 \pm 12.7$ \\
Selenium, $\mu \mathrm{g} / \mathrm{dl}$ & $50 \pm 15.2$ & $140 \pm 40.6$ \\
Hemoglobin, g/dl & $14.4 \pm 0.904$ & $14.9 \pm 10.48$ \\
Fasting serum glucose, $\mathrm{mg} / \mathrm{dl}$ & $108 \pm 21.843$ & $95 \pm 11.20$ \\
\hline
\end{tabular}



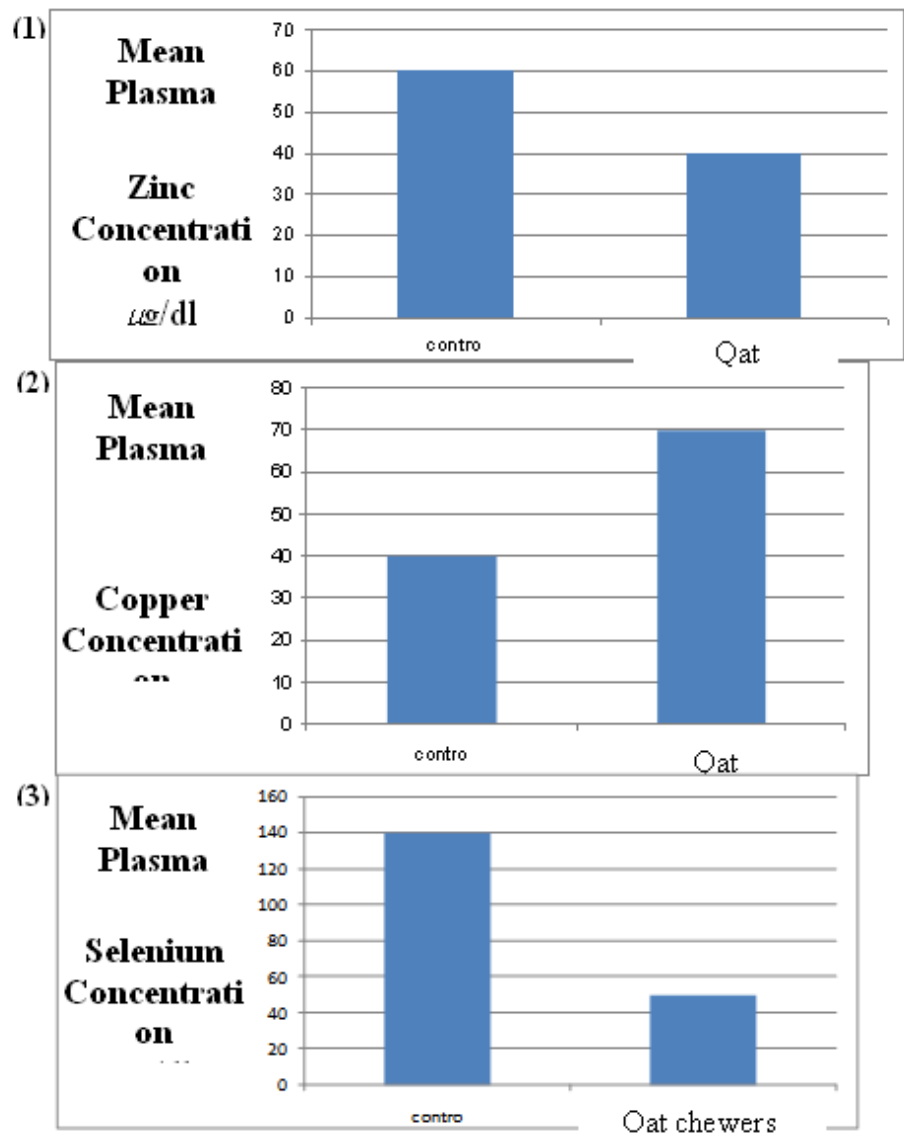

Figure 1,2\&3 show the mean plasma levels of trace elements zinc, copper and selenium in controls and qat chewers.

\section{DISCUSSION}

Zinc, copper and selenium are essential dietary trace metals and are components of critical enzyme systems that play important roles in maintaining DNA integrity by preventing oxidative DNA damage. Zinc and copper are key cofactors in several enzymes, including copper/zinc superoxide dismutases and several DNA repair ${ }^{(22)}$. Selenium is also, a key component of enzymes systems including glutathione peroxidase that removes hydrogen peroxides generated in vivo by free radicals. Selenium is necessary for reproduction and growth in animals and is known to protect against a number of diseases ${ }^{(18)}$.

Although the investigation of the effects of qat has spanned various 
physiological and metabolic effects, to date no data on the plasma levels of zinc, copper and selenium in Yemeni women qat chewers were reported, except for the study of Dughish et al., ${ }^{(23)}$, on the mean of plasma levels of copper and zinc among Yemeni men qat chewers.

The present study assessed the plasma copper, zinc, and selenium status of 24 Yemeni regularly qat chewers compared to 23 Yemeni women non qat chewers of the same age and from the same region.

Our results indicated that the mean plasma levels of zinc in healthy adult women non-qat chewer (control group) was $60 \mu \mathrm{g} / \mathrm{dl}$ which is significantly lower than that of the reference range values of healthy adult women (76-152 $\mu \mathrm{g} / \mathrm{dl})$, and slightly lower than that of the mean plasma zinc level in healthy adult Yemeni men as reported by Dughish et al. ${ }^{(23)}$ was $65 \mu \mathrm{g} / \mathrm{dl}$. The low zinc levels may be attributed to many factors including: The poor diet that may contain little amount of zinc, lack of knowledge of balanced diet, no supplement of zinc to restore the amount of zinc lost as a result of repeat pregnancy and lactation. Alternatively, this value may reflect the normal plasma zinc levels of healthy Yemeni adult women since there is no actual reference range for Yemeni healthy adult women. The current study also found that plasma zinc levels in regular qat chewer $(40 \mu \mathrm{g} / \mathrm{dl})$ were significant lower than control group. The lower level may be due to the effects of tannins which is believed to delay intestinal absorption of zinc (24), and to the amount of minerals, such as copper, cadmium and lead ${ }^{(25)}$. Copper and cadmium act as antagonist to metabolic functions and/or absorption of zinc (David,1988) $^{(26)}$. Our results is in agreement with that of Dughish et al., ${ }^{(23)}$ who reported, low plasma levels of zinc in regular qat chewers but in men.

In contrast, plasma copper levels of qat chewer $(70 \mu \mathrm{g} / \mathrm{dl})$ were highly significantly higher with respect to the control group $(40 \mu \mathrm{g} / \mathrm{dl})$, This concurrent increase of plasma copper levels in qat chewers was accompanied with a decrease in plasma zinc levels indicating the strong correlation and competition between zinc and copper level in terms of their absorption and their ratio in plasma ${ }^{(27-30)}$. That reciprocal relationship might be explained by the fact that qat contains high amount of copper $^{(\mathbf{2 3 , 2 5})}$, and this may be attributed in part to increased plasma levels of copper if compared to control group. Other explanation to the increase of the plasma levels of copper in women qat chewers, qat contains cathinone (pseudoamphetamine) which acts as sympathomimentic agent that stimulates the release of catecholamine (epinephrine and norepinephrine $)^{(2)}$. Copper is normally excreted by the liver via epinephrine stimulation $^{(31,32)}$, so qat can induce copper excretion by secretion of adrenaline. Our results are in agreement with those of Dughish et al. $^{\text {(23) }}$ but these results were among Yemeni men.

Also, the current study revealed that the mean plasma selenium levels in healthy women qat chewer were highly significantly lower than control group. The lower levels of selenium 
can be explained by the facts that qat contains ascorbic acid ${ }^{(33,34)}$, copper and zinc ${ }^{(23,25)}$. Ascorbic acid, copper and zinc are considered as antagonist to selenium ${ }^{(35)}$. Other explanation to low levels of selenium, selenium is a critical constituent of glutathione peroxidase, the major reducing enzyme for both hydrogen peroxide and lipid peroxides (David,1994) ${ }^{(\mathbf{1 8})}$, Qat chewing induces formation of free radicals (Tash et al., 2001) $)^{(34)}$ so, increased oxidative stress could contribute to the observed low selenium.

The daily absorption of selenium due to the effect of tannins in qat (24) participates in part in lowering the level of selenium.

Conclusion: Decreased plasma levels of zinc and selenium and increased plasma levels of copper in qat chewers, makes a question in the relationship between the increases of the incident of cancer in Yemeni people and decrease the levels of essential elements (zinc \& selenium). Therefore, more studies with larger sample size are recommended. In other point, qat chewers must take a supplement of zinc and selenium to avoid their deficiency in plasma.

\section{REFERENCES}

1. Drake PH. (1988): Qat-Chewing in the near East Lancet, 5, 1 (8584):532-3.

2. Kalix P. and Breanden $O$. (1985): Pharmacological aspects of chewing of khat leaves. Pharmacological review, 37(2): 139-164.

3. Kalix P. (1988): Qat a plant with amphetamine effects. Journal of substance Abuse and Treatment, 5(3):163-169.

4. Kalix, P. (1992): Cathinone, a natural amphetamine Pharmacology and Toxicology, 70(2): 77-86.

5. Mulatu E. \& Kassa H. (1998): Evolution of small holder Mixed forming systems in the Harari Highlands of Ethiopia: the shift towards trees and shrub Alemaya University. Ethiopia.

6. Chevallier A. (1996): The Encyclopedia of Medicinal Plants. 336p. Dorling Kindersley Ltd, London.

7. Gebissa E., (2004): Leaf of Allah: Khat and Agricultural Transformation in Harerghe Ethiopia 1875-1991. Oxford.

8. Belew, M. (1997): The magnitude of qat use and its association with health, nutrition and socio-economic status. Community Health Department, Faculty of Medicine, Addis Ababa University 38(1):11-26.

9. Al-Flahi A., Zou JK., Yin XF (2004): Solid phase micro extraction of flavor analysis in Harari chat, Journal of Zhejiang University of Science, 5(4):428431.

10. Szendrei K (1980): the chemistry of chat. Bulletin on Narcotics, 32(3):5-35.

11. Matloob, MH (2003): Determination of cadmium: Lead, copper and zinc in Yemeni Khat by anodic stripping voltammetry. Eastern Mediterranean Health Journal, 9(1-2):28-36.

12. Goldstein G.W (1990). Lead poisoning and brain cell function. 
Environ. Health perspective 89:91-94.

13. Calder, PC, Jackson AA (2000). Under nutrition, infection and immune function. Nutr. Rev., 31(1):3-29.

14. Alebic-Juretic A, Frkovic A (2005): Plasma copper concentrations in pathological pregnancies. J. trace Elem. Med. Bio.,19(2-3) : 191-4.

15. Xiu, Y.M (1996): Trace Elements in Health and Diseases. Biomed. Environ. Sci., 9(23):130-136.

16. Windisch, W (2002): Interaction of chemical species with biological regulation of the metabolism of essential trace elements, Anal. Bional. Chem., 372(3):421-425.

17. Manahan SE (2003): Toxicological Chemistry and Biochemistry. 3 ${ }^{\text {rd }}$ Edition. Boca. Raton, Florida, PRC Press: P., 211-222.

18. David L. (1994): The Nutritional Relation ships of selenium. Journal of orthomolecular medicine vol. 9(2):111-117.

19. Baynes J. and Dominiczak M.H. (1999): Antioxidant defenses and reactive oxygen species (Ros) in Medical Biochemistry Mosby, chapter 11, P. 133-137.

20. Chandra RK. (1980): Communology of nutritional disorders. Year Book Med. Pub. Chicago.54.

21. Laclaustra $M$, Navas-Acien A, Stranges S, Ordovas JM, Guallar E (2009): Serum selenium concentrations and diabetes in U.S. adults: National
Health and Nutrition Examination Survey (NHANES) 2003-2004. Environ Health Perspect 2009, 117:1409-1413.

22. Edwards B. Brown M. Wingo P. Howe H. Ward E. of Ries L. Schrage D. Jamison P. Jemal A Wu X. Friedman C. Harlan L et al. (2005: Annual report to the nation on the status of cancer. J. Nartl. Cancer Inst., 97:1407-27.

23. Dughish. M., Al-Habori M., Al Zabedi. E. (2008): Plasma zinc and copper levels among Yemeni khat chewers. E.J.B. M.B., 26(special Issue):586-594.

24. Halbach (1972): Medical aspects of chewing of qat leave WHO Bul., 47(1):21-29.

25. Alkadi, H.O., Noman, M.A., AlThobhani, A.K., Al-Mekhlafi, F.S., Raja'a, YA (2002): Clinical and experimental evaluation of the effect of khat-induced myocardial infarction. Saudi Medical Journal 23: 1195- 1198

26. David L (1988): The Nutritional Relation ships of zinc. J.Orth. Med. vol .3(2):63-67.

27. Crofton RW, Gvosdanovicd, Gvozdanovic S, et al., (1989): Inorganic zinc \& intestinal absorption of ferrous iron. Am. J. Clin. Nutr., 50(1): 141-4.

28. Dawson RB, Albers J, McGanity WJ (1990): Serum zinc changes due to iron supplementation in teen-age pregnancy, am J. clin. Natr., 50:848.

29. Lai H, Lai S, Shor-Posner G, Ma F, Trapido E, Baum MK (2001): Plasma zinc, copper, copper: zinc ratio, and survival in a cohort of HIV- infected 
homosexual men. J. Acquire, Immune Oefic. Syndr., 27(1): 5662.

30. Food and Nutrition Board Institute of Medicine (2001): Zinc: Dietary reference intakes for vitamin A, vitamin $\mathrm{k}$. boron, chromium, copper, iodine iron, manganese, molybdenum, nickel, PP: 42-501.

31. Evans, G.W, Cornatzer WE (1971): Biliary copper excretion in the Rat. Proc. Soc. Exp. Biol. Med. 136(3):719-721.

32. Henkin RI (1974): Trace element Metabolism in Animals. Vol II. Hoekstra, W.G., et al., Eds Univ. Park Press, Med.

33. Mustard M.J. (1952): Ascorbic acid content of some miscellaneous tropical and subtropical plants and plants products. Food Research 17:3135.

34. Ekram F. Al-Eryani (2001): The effect of qat administration on free radicals metabolism and antioxidant status in rats. Thesis of The Master degree in Biochemistry, Ain Shams University

35. Martin RF., Young VR., Blumberg J., Janghorban (1989): Ascorbic acid selenite interactions in human studies with and oral dose of 74Seo3-2, Am. J. Clin, Nutr., 49(5): 862869. 
قياس مستويات الزنك ، النحاس ، والسيلينيوم في مصل الدم للسيدات اليمنيات ماضغي القات مالمي

\author{
اكرام الابيرياني ـ منبيره دغش ـ ملهم الهابوري \\ قسم الكيمياء الحيوية ـ كلية الطب و العلوم الصحية ـ جامعة صنعاء ـ اليمن
}

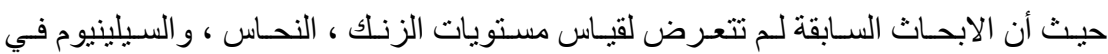

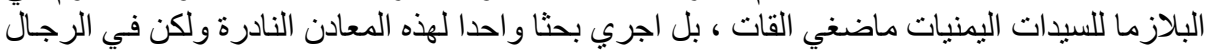

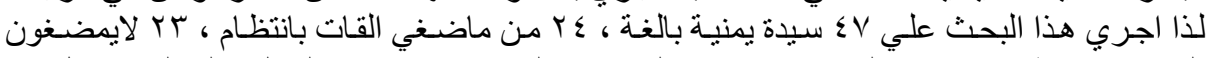

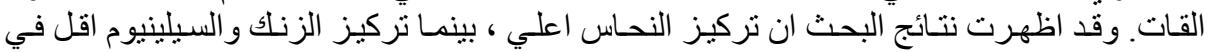

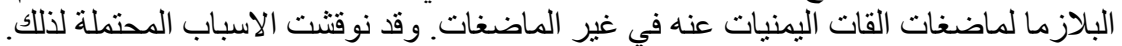

